\title{
The effects of World Health Organization chemotherapy on imported leprosy in Auckland, New Zealand, 1983-90
}

\author{
J. CORNWALL, G. CAMERON* \& \\ R. B. ELLIS-PEGLER \\ Infectious Disease Unit and Clinical Microbiology Laboratory*, \\ Auckland Hospital, Auckland, New Zealand
}

Accepted for publication 26 February 1993

Summary Between January 1983 and December 1990 in Auckland, New Zealand, 87 patients (28 paucibacillary disease (PBD) and 59 multibacillary disease (MBD)) commenced WHO multidrug therapy (MDT).

All were immigrants from the Pacific Islands (65) or Asia (22). A total of 57 patients had already received non-WHO regimens, some continuously, but often intermittently, for many years; 30 patients received WHO MDT only. By December 1990, 50 had completed treatment, with 1 relapse and 1 late reaction, both in patients with PBD treated with WHO MDT only. There have been no relapses in those treated with WHO MDT after prior leprosy treatment.

In those with MBD, type II leprosy reactions were less common (16\%) in those treated only with WHO MDT than in those treated continuously before 1983 with older regimens (64\%). Type I leprosy reactions occurred in about $20 \%$ of both these groups. The bacterial index fell faster in those who had had a prolonged prior treatment beginning WHO MDT than in those starting WHO MDT as their initial leprosy chemotherapy.

Overall we found WHO MDT was well accepted and the compliance good, but 13 patients (15\%) left Auckland before treatment was completed and $6(7 \%)$ during follow up.

\section{Introduction}

Auckland, New Zealand, has the largest Polynesian population in the world. For many years large numbers of immigrants have entered New Zealand from the South Pacific islands of Western Samoa, the Cook Islands, the Tokelau Islands, Tonga and Fiji. Recently refugees have arrived from South-East Asia. Many of the inhabitants of these countries suffer from endemic leprosy, therefore people infected with Mycobacterium leprae have entered New Zealand. Leprosy does not occur in people who have not lived outside New Zealand.

We report here our experience of leprosy using the World Health Organization multi- 
drug therapy regimen (WHO MDT) at the Auckland Hospital infectious disease unit from the introduction of this treatment in January 1983 to December 1990.

In 1982 WHO officially recommended that leprosy should be treated with MDT. ${ }^{1}$ This decision was made because of the growing incidence of both primary and secondary dapsone resistant leprosy and the recognition that paucibacillary (PB) disease (PBD) needed shorter treatment than was then generally being used. Paucibacillary disease includes indeterminate polar tuberculoid and borderline tuberculoid leprosy in the Ridley-Jopling classification ${ }^{2}$ and in 1982 included cases with a bacteriological index (BI) of $1+$ according to the Ridley scale. This was modified in 1988 to include only those with negative bacteriology. Multibacillary disease (MBD) is all mid-borderline to lepromatous leprosy and from 1988 also included any with a positive BI with particular care in the classification of borderline tuberculoid disease. ${ }^{3}$

World Health Organization MDT for PBD is 6 months of daily dapsone with monthly rifampicin; for MBD it is daily clofazamine and dapsone with monthly rifampicin and clofazamine given under supervision. It is recommended that MBD treatment continue until skin smears are negative or for a minimum of 2 years.

\section{Methods}

Demographic, investigational, treatment and outcome data (i.e. age, sex, ethnicity, duration of previous treatment, disability, treatment, drug side effects, reactions, compliance, BI and outcome) were taken from the case notes of all patients treated for leprosy at the Auckland Hospital infectious disease unit from 1983. All patients are managed as outpatients unless particular complications (e.g. severe reaction, osteomyelitis) necessitate admission, which was uncommon.

A disability index was assessed from records of clinical examination and the maximum disability at any stage was recorded. Disability was graded as minor, moderate or severe. ${ }^{4}$

Treatment was described as: WHO MDT, where it was absolutely as recommended, modified WHO MDT (i.e. WHO MDT plus extra drug or extended duration of treatment) or other (i.e. that not providing minimum MDT).$^{5}$

Reactions were classified as Type I or II. We defined long-term reaction treatment as courses of prednisone or thalidomide (for Type II reactions) given for longer than 3 months.

Compliance was evaluated by checking the dates on which each monthly pulse dose was given. We classified a patient as compliant if he/she took the dose within 14 days of the due monthly date. All monthly doses were given under supervision, either to patients returning to the infectious disease unit or by public health nurse visits at home or work.

The BI was measured yearly using the Ridley-Jopling Classification from split skin smears examined by G.C. On initial examination bilateral smears from the nose, ear lobes, elbows, fingers and skin lesions were tested and subsequently 4 to 6 sites were tested. Testing of finger dorsa was added in the mid-1980s but, because patients found this uncomfortable, they were tested again only towards the expected end of treatment. For the same reason, we rarely re-evaluated nasal smears after the usual intial rapid clearing from that site.

Statistical analysis was done by the $\chi^{2}$ test for univariate analysis and Student's $t$-test for group comparison. A logistic regression model was used with disability as the 
Table 1. Yearly patient numbers treated in Auckland ${ }^{5}$

\begin{tabular}{lrrrrrrrrrr}
\hline & \multicolumn{7}{c}{ Year MDT began in Auckland } \\
\cline { 2 - 10 } & 1983 & 1984 & 1985 & 1986 & 1987 & 1988 & 1989 & 1990 & Total \\
\hline $\begin{array}{l}\text { Cases in } \\
\quad \text { New cases }\end{array}$ & 2 & 1 & 4 & 1 & 2 & 3 & 3 & 5 & 21 \\
$\quad \begin{array}{c}\text { Additional } \\
\text { Cases out }\end{array}$ & 45 & 6 & 6 & 6 & 3 & 9 & 6 & 6 & 87 \\
$\quad$ Early exit & 1 & 2 & 1 & 2 & 0 & 3 & 2 & 3 & 14 \\
$\quad$ Completed & 9 & 6 & 21 & 1 & 2 & 2 & 7 & 2 & 50 \\
Registered & 35 & 33 & 17 & 20 & 21 & 25 & 22 & 23 & \\
\hline
\end{tabular}

1. New cases: cases newly detected in the year indicated.

2. Additional: includes all cases whose treatment with MDT was started in Auckland in the year indicated.

3. Early exit: left the Auckland area prior to finishing treatment because of emigration (13) or death (1).

4. Completed: treatment with MDT completed in the year indicated.

5. Registered: those registered as leprosy cases and on treatment at year end. (It does not include those under surveillance.)

dependent variable and sex, type of leprosy, and ethnicity as the explanatory variables. BI were analysed as ordinal variables using the non-parametric Wilcoxon rank sum test.

\section{Results}

A total of 87 patients have been registered as having leprosy between January 1983 and December 1990 (Tables 1 and 2).

We divided patients into 2 treatment groups; i.e. those who had been treated before beginning WHO regimens (prior treatment group) and those who had not been treated before beginning WHO regimens (no prior treatment group) (Figure 1).

\section{Prior treatment group (57 patients) (Table 3)}

These patients had received treatment of various sorts before being transferred to WHO MDT regimens. They were divided into 2 further sub-groups.

(a) Uninterrupted treatment group (23 patients). These patients had usually been diagnosed in Auckland after the mid-1970s and had remained under our care for their entire management. They had usually been treated with 6 to 12 weeks of initial dapsone and rifampicin with or without additional clofazimine followed by dapsone monotherapy. Our own records provide reliable information about these patients -10 of these patients were from the Cook Islands, 6 from Samoa, 2 from Tonga, 3 from Cambodia and 2 from Vietnam.

(b) Interrupted treatment group (34 patients). These patients were treated with various regimens, usually prolonged dapsone monotherapy generally started in the Pacific Islands before the 1970s and subsequently continued in Auckland. In the majority 
Table 2. Table of epidemiological data

\begin{tabular}{|c|c|c|c|c|c|c|c|c|}
\hline & \multirow[b]{2}{*}{ Total } & \multicolumn{2}{|c|}{ Sex } & \multirow[b]{2}{*}{ Ratio } & \multicolumn{2}{|c|}{ Race } & \multirow{2}{*}{$\begin{array}{c}\text { Age at diagnosis } \\
\text { (mean + S.D.) } \\
\text { (years) }\end{array}$} & \multirow{2}{*}{$\begin{array}{l}\text { Duration of treatment } \\
\text { prior to WHO MDT } \\
\text { (mean } \pm \text { S.D. }) \\
\text { (years) }\end{array}$} \\
\hline & & $\mathrm{M}$ & $\mathrm{F}$ & & Pacific & Asian & & \\
\hline \multicolumn{9}{|l|}{ Prior treatment } \\
\hline 1. Interrupted & 34 & 19 & 15 & $1: 0.75$ & 31 & 3 & $20( \pm 10)$ & $15( \pm 11)$ \\
\hline (a) Paucibacillary & 8 & 3 & 5 & & 7 & 1 & $14( \pm 6)$ & $5(+3)$ \\
\hline (b) Multibacillary & 26 & 16 & 10 & & 24 & 2 & $21( \pm 10)$ & $18( \pm 11)$ \\
\hline 2. Uninterrupted & 23 & 15 & 8 & $1: 0.57$ & 18 & 5 & $27( \pm 13)$ & $6( \pm 11)$ \\
\hline (a) Paucibacillary & 9 & 5 & 4 & & 5 & 4 & $27( \pm 15)$ & $5( \pm 3)$ \\
\hline (b) Multibacillary & 14 & 10 & 4 & & 13 & 1 & $27( \pm 12)$ & $7( \pm 5)$ \\
\hline No prior treatment & 30 & 18 & 12 & $1: 0 \cdot 66$ & 16 & 14 & $34( \pm 14)$ & Not applicable \\
\hline (a) Paucibacillary & 11 & 5 & 6 & & 7 & 4 & $35( \pm 16)$ & \\
\hline (b) Multibacillary & 19 & 13 & 6 & & 9 & 10 & $33( \pm 12)$ & $* *$ \\
\hline
\end{tabular}

1. $\mathrm{M}$ male, $\mathrm{F}$ female.

2. ** 9/19 had begun WHO MDT elsewhere: mean duration of their previous WHO MDT was $3( \pm 1)$ years. 


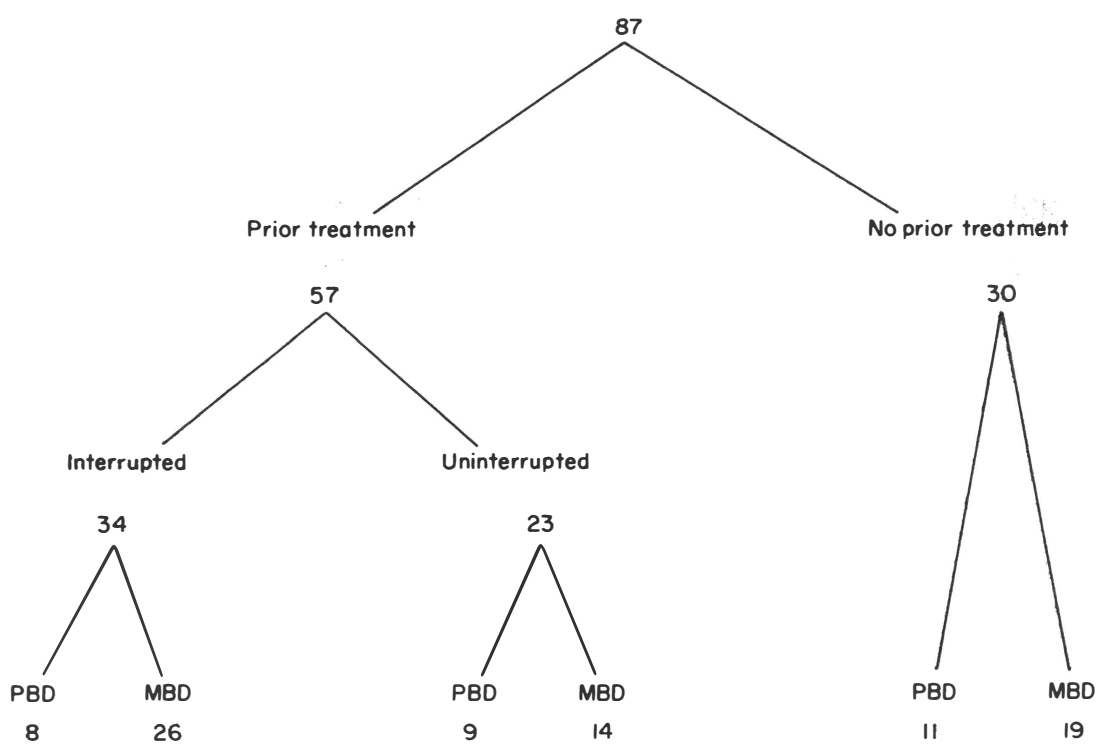

Figure 1. Patient summary.

treatment was further interrupted by return visits to the Pacific Islands and details of treatment there were difficult to define accurately. In all, 15 of these patients were from Samoa, 13 from the Cook Islands, 3 from Fiji (1 each from native Fijian, Fiji Indian and Fiji Malay stock), and 1 each from Tonga, the Tokelau Islands and Cambodia.

The mean $15( \pm 11)$ years of prior treatment in the interrupted group is significantly longer than the mean $6( \pm 4)$ years in the uninterrupted group $(t=3 \cdot 89, \mathrm{df}(54) ; p<0 \cdot 001)$.

\section{No prior treatment (30 patients) (Table 4)}

These patients had had no previous treatment before beginning WHO MDT -21 began their WHO Regimen in Auckland and 9 continued WHO MDT treatment begun elsewhere, mostly in refugee camps in South-East Asia; 11 were from Samoa, 5 from the Cook Islands, 7 from Cambodia, 3 from India and 1 each from Laos, Vietnam, the Pillippines and Pakistan.

\section{EPIDEMIOLOGY}

Details of sex, ethnicity, age at diagnosis and duration of previous treatment are summarized above and in Table 2. Patients were predominantly from Western Samoa (32) and the Cook Islands (28), but there was a higher proportion of South-East Asians (16), particularly Cambodians (11) among cases diagnosed since 1983. There was a nonsignificant trend for males to have MBD more than females $\left(\chi^{2}=3.09 p<0 \cdot 1\right)$. The percentage distribution of PBD and MBD amongst the two main ethnic groups (Pacific Islanders and Asians) was similar. There has been an increase in mean age and a decreased duration of disease at diagnosis over the years. 
Table 3. Data summary for patients in prior treatment group

\begin{tabular}{|c|c|c|c|c|c|c|}
\hline \multirow{5}{*}{$\begin{array}{l}\text { Classification: } \\
\text { Skin smear: }\end{array}$} & \multicolumn{6}{|c|}{ Prior treatment group (57) } \\
\hline & \multicolumn{3}{|c|}{ Interrupted (34) } & \multicolumn{3}{|c|}{ Uninterrupted (23) } \\
\hline & \multirow{3}{*}{$\begin{array}{c}\text { PBD } 8 \\
-v e \\
8\end{array}$} & \multicolumn{2}{|c|}{$26 \mathrm{MBD}$} & \multirow{3}{*}{$\begin{array}{c}\text { PBD } 9 \\
- \text { ve } \\
8\end{array}$} & \multicolumn{2}{|c|}{$14 \mathrm{MBD}$} \\
\hline & & - ve & $+v e$ & & - ve & + ve \\
\hline & & 15 & 11 & & 8 & 6 \\
\hline \multicolumn{7}{|l|}{ Regimen: } \\
\hline WHO & 5 & 9 & 8 & 7 & 6 & 6 \\
\hline Modified & 3 & 0 & 0 & 2 & 0 & 0 \\
\hline Other & 0 & 6 & 3 & 0 & 2 & 0 \\
\hline Side effects: & 0 & 0 & 0 & 0 & 2 & 2 \\
\hline \multicolumn{7}{|l|}{ Reactions: } \\
\hline Type I & 0 & 1 & 0 & 0 & 0 & 1 \\
\hline Type II & 0 & 0 & 6 & 0 & 1 & 6 \\
\hline \multicolumn{7}{|l|}{ Outcome: } \\
\hline Early exit & 1 & 0 & 4 & 0 & 1 & 2 \\
\hline Continue & 0 & 1 & 2 & 0 & 0 & 4 \\
\hline \multicolumn{7}{|l|}{ Complete } \\
\hline Lost to f/up & li & 1 & 0 & 0 & 2 & 0 \\
\hline f/up & 6 & 13 & 5 & 9 & 5 & 0 \\
\hline $\begin{array}{l}\text { Median duration } \mathrm{f} / \mathrm{u} \text { (months) } \\
\text { (range) (months) }\end{array}$ & $\begin{array}{c}23 \\
(12-36)\end{array}$ & $\begin{array}{c}32 \\
(6-48)\end{array}$ & $\begin{array}{c}9 \\
(5-60)\end{array}$ & $\begin{array}{c}36 \\
(12-50)\end{array}$ & $\begin{array}{c}58 \\
(12-84)\end{array}$ & nil \\
\hline
\end{tabular}

f/u: follow up regimen: see text for details.

DISABILITY

Disability (Table 5) was mild in $37(42 \%)$, moderate in $24(28 \%)$ and severe in $26(30 \%)$. Paucibacillary disease was associated with less disability than $\operatorname{MBD}\left(\chi^{2}=15, p<0 \cdot 0001\right)$. There was no significant difference in disability with respect to sex, ethnicity, treatment group or year of diagnosis.

\section{TREATMENT REGIMENS}

\section{Prior treatment (57 patients) (Table 3)}

(i) Uninterrupted treatment group (23 patients)

(a) PBD (9 patients)

In total, 7 patients received WHO MDT and 2 modified WHO MDT. These latter 2 had 2 years MB MDT: 1 because of extensive clinical BT disease and 1 because previous long-term low dose dapsone monotherapy (100 mg/week) raised concern about dapsone resistance, although it was not proved.

(b) MBD (14 patients)

In total, 12 patients received WHO MDT and 2 were given other treatment. Of the latter, dapsone was omitted in 1 because of previous haemolysis and the other, 
Table 4. Data summary for patients in group with no prior treatment

\begin{tabular}{|c|c|c|}
\hline \multirow[b]{2}{*}{ Classification: } & \multicolumn{2}{|c|}{ No prior treatment $(30)$} \\
\hline & PBD 11 & $19 \mathrm{MBD}$ \\
\hline \multicolumn{3}{|l|}{ Regimen: } \\
\hline WHO & 8 & 19 \\
\hline Modified & 3 & 0 \\
\hline Other & 0 & 0 \\
\hline Side effects: & 0 & 1 \\
\hline \multicolumn{3}{|c|}{ Reactions during treatment: } \\
\hline Type I & 2 & 3 \\
\hline Type II & 0 & 3 \\
\hline \multicolumn{3}{|l|}{ Outcome: } \\
\hline Early exit & 1 & 5 \\
\hline Continue & 3 & 13 \\
\hline \multicolumn{3}{|l|}{ Complete } \\
\hline Lost to f/up & 2 & 0 \\
\hline Relapse & 1 & 0 \\
\hline Late reaction & 1 & 0 \\
\hline F/up & 4 & 1 \\
\hline Median duration $\mathrm{f} / \mathrm{up}$ & 18 & 10 \\
\hline
\end{tabular}

Table 5. Disability according to ethnic group, disease classification, sex and age

\begin{tabular}{|c|c|c|c|c|c|c|c|}
\hline \multirow{3}{*}{$\begin{array}{l}\text { Disease } \\
\text { Classification }\end{array}$} & \multicolumn{6}{|c|}{ Disability } & \multirow[b]{3}{*}{ Total } \\
\hline & \multicolumn{2}{|c|}{ Minor } & \multicolumn{2}{|c|}{ Moderate } & \multicolumn{2}{|c|}{ Severe } & \\
\hline & $\mathbf{M}$ & $\mathrm{F}$ & M & $\mathrm{F}$ & $\mathbf{M}$ & $\mathrm{F}$ & \\
\hline \multicolumn{8}{|c|}{ Pacific Islanders } \\
\hline PBD & 6 & 8 & 2 & 1 & 1 & 1 & 19 \\
\hline MBD & 9 & 4 & 7 & 8 & 13 & 5 & 46 \\
\hline \multicolumn{8}{|l|}{ Asians } \\
\hline PBD & 2 & 4 & 2 & 1 & 0 & 0 & 9 \\
\hline MBD & 2 & 2 & 3 & 0 & 5 & 1 & 13 \\
\hline Total & 19 & 18 & 14 & 10 & 19 & 7 & 87 \\
\hline
\end{tabular}

already smear negative with prolonged prior treatment, had only 12 months MB MDT because of noncompliance.

(ii) Interrupted treatment group (34 patients)

(a) PBD (8 patients)

In total, 5 patients received WHO MDT and 3 modified WHO MDT. Of the latter, all 3 had 2 years MB MDT, for the same reasons as in the PBD group with prior uninterrupted treatment discussed above.

(b) $\mathrm{MBD}$ (26 patients)

In all, 17 patients received WHO MDT and 9 were given other treatment. Of those latter 9, 1 who was already smear negative after prolonged treatment had only 6 months MB MDT because of noncompliance, 1 had had previous dapsone 
haemolysis and 5 refused dapsone because of their concerns about its role in inducing reactions; 2 did not receive clofazimine, 1 because of concern about skin discolouration and another because of concern about other side effects.

2. No prior treatment (30 patients) (Table 4)

(a) PBD (11 patients)

In all, 8 received WHO MDT and 3 received modified WHO MDT. Of these latter 3,1 received 30 months $\mathrm{PB}$ MDT because of a persistently active single skin lesion and 2 received 2 years of MB MDT because of extensive BT disease.

(b) MB (19 patients)

All received WHO MDT.

In all patients, where we omitted 1 drug of WHO MDT, the other components of the regimen were continued. We did not add alternative agents.

\section{SIDE EFFECTS}

\section{Prior treatment (Table 3)}

Side effects were suffered by 4 of 57 patients (7\%) - 1 man with MBD who had received rifampicin 10 years earlier developed rifampicin allergy af ter the 3rd monthly dose of WHO MDT. While on MB MDT 2 Pacific Islanders developed dapsone haemolysis, and 1 clofazamine enteritis.

2. No prior treatment (Table 4)

A Cambodian man ( 1 of 30 patients $(3 \%)$ ) developed a side effect, dapsone haemolysis.

Overall, dapsone haemolysis occurred in 5 of 87 patients (6\%): 3 while receiving WHO MDT and 2 during prior treatment.

\section{REACTIONS}

\section{Prior treatment (Table 3)}

(a) PBD: none of 17 had reactions.

(b) MBD: in total 14 of 40 patients (35\%) had reactions, of whom 12 had positive BI.

i. Uninterrupted treatment group -7 of 14 patients $(50 \%)$ had 8 reactions; 6 had type II reaction and 1 had both type I and type II reactions; and 6 needed longterm treatment, 5 changing to thalidomide from prednisone; 3 had first been treated for reactions before the introduction of WHO MDT.

ii. Interrupted treatment group -7 of 26 patients ( $27 \%$ ) had reactions; 6 had type II reactions and 1 a type I reaction; 2 of those with type II reactions remain on prednisone, 1 needed no treatment and the remaining 3 changed to thalidomide; 4 had been treated for reactions before the introduction of WHO MDT. 
Table 6. Comparative reaction rates on earlier non-WHO regimens and WHO regimens alone

\begin{tabular}{|c|c|c|c|c|}
\hline & \multicolumn{4}{|c|}{ Reactions } \\
\hline & \multicolumn{2}{|c|}{$\begin{array}{l}\text { During prior, uninterrupted } \\
\text { non-WHO treatment before } 1983\end{array}$} & \multicolumn{2}{|c|}{$\begin{array}{l}\text { During WHO treatment of group } \\
\text { not previously treated, af ter } 1983\end{array}$} \\
\hline & Type I & Type II & Type I & Type II \\
\hline PBD & $1 / 9 \quad(11) \dagger$ & $0 / 9$ & $3 / 11$ & $0 / 11$ \\
\hline MBD & $4 / 14$ (29) & $9 / 14(64)^{*}$ & $3 / 19$ (16) & $3 / 19(16)^{*}$ \\
\hline Total & $5 / 23(22)$ & $9 / 23$ (39) & $6 / 30(20)$ & $3 / 30(10)$ \\
\hline
\end{tabular}

\footnotetext{
* Comparison $\chi^{2}=8 \cdot 3, p<0 \cdot 001$. Notes:

$\dagger$ Numbers in parentheses are percentages.

1. Some patients had both Type I and II reactions: these figures refer to reactions, not patients.

2. The data in the group treated before 1983 ref ers to reaction rates during that time on non-WHO regimens, and not to reaction rates occurring in this group while on WHO regimens after 1983 .
}

\section{No prior treatment (Tables 4 and 6)}

(a) PBD: 3 of 11 patients $(27 \%)$ had type I reactions; 2 patients developed reactions on PB MDT, and needed long-term prednisone, and in 1 of them the reaction still continued after the completion of PB MDT, and because of clinical concern about a possible late relapse of disease due to steroid treatment, MB MDT was started 2 months after finishing PB MDT, and continued for 2 years. Prednisone was required for 20 months of this time. The 3rd patient had 6 months PB MDT in 1983, and at a routine review in 1989 was discovered to have developed bilateral ulnar nerve palsies and local inflammatory swelling. He was then given 12 months MB MDT because skin smears were reported to show BI 4+ at 1 site, but this was never confirmed on repeat smears. We therefore took the view that this was a reaction that had been both clinically and microbiologically misdiagnosed as relapse and MB MDT was stopped. He had developed no further abnormalities after 2 years follow up. Thus 1 of $11(9 \%)$ had a late reaction.

(b) MBD: 5 of 19 patients $(26 \%)$ had 6 reactions; 2 patients had type I reactions, 2 type II and 1 both; and 3 needed long-term steroid treatment.

Detailed records were available for the treatment given before the introduction of WHO MDT to the uninterrupted treatment group (Table 6). There was no difference in type I reaction rates between this group during earlier treatment and those treated only with WHO MDT: type I reactions occurred in about $20 \%$ of both. In contrast $64 \%$ ( 9 of 14) of our patients with MBD on uninterrupted treatment before 1983 had type II reactions compared with $16 \%$ (3 of 19$)$ on WHO MDT $\left(\chi^{2}=8 \cdot 3, p<0.001\right)$. Once MBD patients with prior treatment changed to WHO MDT, type II reactions were virtually limited to those with bacteria still present (i.e. B1 $\geqslant 1+)$ on transfer; $71 \%(12$ of 17$)$ with $\mathrm{B} 1 \geqslant 1+$ had reactions subsequently compared with $4 \%$ ( 1 of 23$)$ in those with $\mathrm{B} 1=0\left(\chi^{2}=19 \cdot 6\right.$, $p<0.001)$.

\section{COMPLIANCE}

Compliance was good, with the majority of doses given on time, though for some this 


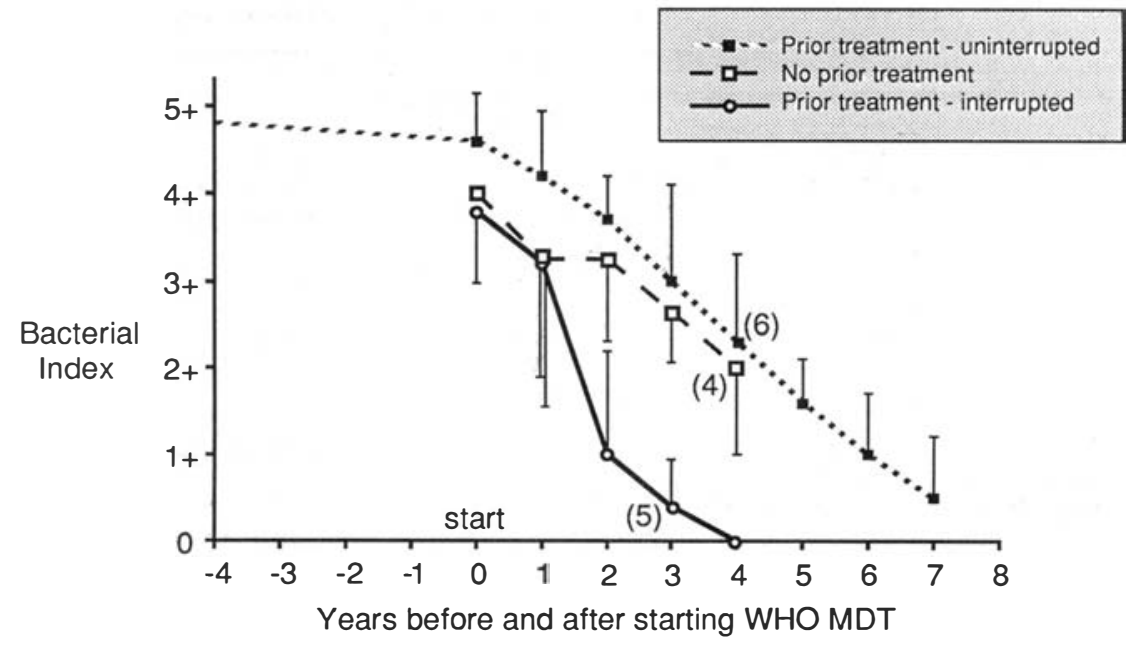

Figure 2.

required a great deal of work by medical and district health nursing staff. Compliance with PBD treatment was better than for MBD treatment, with a mean $91 \%( \pm 16.9)$ of doses compliant for PBD and a mean 87\% ( $\pm 13 \cdot 6)$ for $\operatorname{MBD}(t=4 \cdot 5 \operatorname{df}(84) p<0 \cdot 001)$. There was no difference in compliance with age, ethnicity, sex or treatment group.

\section{BACILLARY INDEX IN THOSE WITH MBD}

Of 59 with MBD, 23 who had had prior treatment were smear negative at the time of transfer to MDT. Of the remaining 36,28 had $\mathrm{BI}>1,6 \mathrm{BI}=1$, and $2 \mathrm{BI}=0$ (1 transferred from South-East Asia, already smear negative, and 1 with clinically MBD) at the start of the Auckland WHO MDT. In 15 of these patients with $\mathrm{BI}>1$ we have yearly BI available for 4 years while taking WHO MDT and this information is shown in Figure 2. While there was no difference in the initial BI between groups, there was a significant difference between counts in the interrupted and uninterrupted groups in years 3 and $4\left(p=0.01 \mathrm{n}_{1} \mathrm{n}_{2}\right.$ $5,6 t=16$ in both years (Wilcoxon rank Sum test)). The mean $11 \cdot 2( \pm 8 \cdot 7)$ years of prior treatment in the interrupted group is longer than the mean $3.6( \pm 2.4)$ years in the uninterrupted group though not significantly so $(t=1 \cdot 88, \operatorname{df}(9), p<0 \cdot 1)$.

\section{OUTCOME}

By 31 December 199050 patients had completed their treatment ( 35 had completed WHO MDT, 5 modified WHO MDT and 10 other regimens); 14 patients did not finish MDT: 13 left Auckland, and 1 died on an unrelated cause. In all, 23 were registered (i.e. continuing treatment) on 31 December 1990.

We attempted a follow up of all patients for up to 5 years. Outcome according to treatment group is shown in Tables 3 and 4 . Of those treated only with PB MDT, 1 patient has relapsed: a 20-year-old Samoan woman diagnosed with PBD in 1983 with BI $=0$ but who had extensive clinical disease. She completed 10 months PB MDT with $100 \%$ compliance, but on review at 1 year had relapsed with extensive clinical disease and BI had 
increased to $3+$. MB MDT was started but she returned to Samoa after 2 months. Our incidence of relapse for PB disease in those with no prior treatment is thus 1 in $11(9 \%)$. None of the 15 patients followed up who took PB MDT after prior treatment has relapsed.

So far only 1 patient with MBD and no prior treatment has finished WHO MDT so no relapse data is available for this group. None of the 23 patients followed up af ter receiving WHO MDT after prior treatment has relapsed.

\section{Discussion}

Despite the smaller numbers, our experience in Auckland with immigrant patients suffering from leprosy taking WHO MDT has many similarities to reports elsewhere. ${ }^{3,6,7,8,9,10} \mathrm{An}$ increase in cases of leprosy reported to the Centers for Disease Control in the U.S.A. was noted between 1978 and 1988, due mainly to ref ugees suffering from leprosy who came from Cambodia, Vietnam and Laos. ${ }^{6}$ That experience is similar to ours.

Leprosy is said to have disappeared from the Cook Islands, with no active cases registered in 1989. ${ }^{11}$ We still have Cook Islanders with active disease in our programme in 1993, making us uncertain about that statement. In 1990 there were 25 cases registered in Western Samoa. ${ }^{11}$ The proportion of new patients with PBD $(52 \%)$ and MBD $(48 \%)$ is similar to both Western Samoa (44\% PBD) ${ }^{7}$ and Thailand (5\% indeterminate, $42 \%$ tuberculoid, $36 \%$ borderline, and $17 \%$ lepromatous) ${ }^{8}$ In our total patient group PBD $(32 \%)$ is under-represented because immigrants previously treated for PBD did not present to us. The increase in mean age at diagnosis over the years has been noted elsewhere and remains unexplained. ${ }^{3}$ Like others we found men more often affected ${ }^{7,8}$ and more likely to have MBD, $,^{4,7}, 8$ though we did not find the difference in disability between sexes that has been reported elsewhere. ${ }^{4}$

In total, $30 \%$ of our patients were severely disabled, which is comparable to the $27 \%$ in Thailand, ${ }^{8}$ but much more than the $5-17 \%$ found in Trinidad and Tobago ${ }^{9}$ and in the total population surveys in Malawi where only $10 \%$ had any disability. ${ }^{4}$ Our higher proportion could reflect ethnic difference in disease severity or in seeking medical care, or a more disabled selected immigrant population. Progression of disability while under our care was rare.

Dapsone haemolysis occurred in $5 \%$ of our patients. The incidence of significant haemolysis quoted by others varies from 'rare' to $16 \% .^{12,13}$ Factors which are often associated with haemolysis, such as increased age, high dapsone dose, and glucose-6phosphate dehydrogenase deficiency ${ }^{12-14}$ did not occur in our patients. Clofazamine skin pigmentation was of concern to only 1 of our patients, and in Samoa ${ }^{7}$ and elsewhere ${ }^{3,9}$ there has generally been acceptance of this side effect. Rifampicin allergy ${ }^{14}$ and clofazamine enteritis ${ }^{14,15}$ are rare.

WHO have stated ${ }^{3}$ that 'type I reactions have become relatively more prominent in leprosy control programmes since the introduction of MDT, probably because of better monitoring of patients'. We found no such increase, with about $20 \%$ having type I reactions before and after WHO MDT introduction. In contrast, 16\% (3 of 19) of our patients treated only with WHO MDT for MBD had type II reactions, significantly less than the $64 \%$ ( 9 of 14 ) of our MBD patients who we had treated uninterruptedly before 1983. Type II reaction rates between $9 \%$ and $43 \%$ are reported for WHO MDT of MBD. ${ }^{9,10}$ We found that for patients transferring to WHO MDT, type II reactions were 
common in those with positive smears $(71 \%)$ but rare in those who were smear negative.

Our difficulty in differentiating late reaction from relapse is similar to the experience of others. ${ }^{9,10}$ Late reactions have been reported as occurring most frequently in the first 6 months after treatment but may still occur up to 4 years, ${ }^{16}$ and in our case, ignoring the diagnostic uncertainty, 6 years after treatment stopped.

Compliance with treatment while in Auckland is good, but the high proportion of patients emigrating prior to or just as treatment finishes is of concern, both for completion of treatment and the detection of late reaction or relapse. The Western Samoan treatment programme has the same problem, with the frequent movement of patients to American Samoa, New Zealand and Hawaii. ${ }^{7}$

While WHO MDT has generally been shown to speed up clinical improvement ${ }^{3}$ the rate of fall of BI does not differ significantly between various drug regimens, presumably because BI measures both dead and viable organisms, which are eliminated by a process unrelated to antimicrobial treatment. ${ }^{17} \mathrm{We}$ found the most rapid rate of $\mathrm{BI}$ fall in the group with prior interrupted treatment. This was the group with the longest duration of previous treatment and it is this long duration of treatment which is the likely reason for the rate of fall being the most rapid of the 3 groups. (This is not an argument in support of interrupted treatment!)

Active lesions persisted at the end of treatment in $9 \%$ (1 of 11$)$ with PBD, at the lower end of incidences between $4 \cdot 3 \%$ and $27 \cdot 8 \%$ quoted elsewhere. ${ }^{17}$ We elected to continue treatment until lesions were clinically inactive. ${ }^{13}$ Our treatment for MBD is conservative, treating up to 2 sets of negative skin smears taken 12 months apart.

Our single patient who relapsed had extensive initial clinical disease, though with a negative BI. Following this episode in 1984, we treated patients with extensive BT disease and $\mathrm{BI}=1+$ or $\mathrm{B}=0$, with 2 years $\mathrm{MB}$ MDT, contrary to the then current official recommendations ${ }^{1}$ though in line with, but still more stringent than, recent recommendations. ${ }^{3}$ This early decision may well have decreased our relapse rate. We have followed up insufficient numbers af ter completion of WHO MD MDT to enable us to predict relapse. However, we have seen no relapses so far in the 23 patients we have been able to follow up who took WHO MB MDT after prior treatment.

In conclusion we have found WHO MDT well accepted, and our experience of reactions and relapse, within the limits imposed by small numbers, is similar to others.

\section{Acknowledgments}

Our thanks to Mrs E. Robinson (New Zealand Health Research Council biostatistician) for help with statistical analysis, and to Mrs D. Eketone for typing the manuscript.

\section{References}

1 WHO Study Group. Chemotherapy of leprosy for control programme. Technical Report Series 675. WHO: Geneva, 1982.

2 Ridley DS, Jopling WH. Classification of leprosy according to immunity: a five group system. Int J Lepr, 1966; 34: 255-73.

3 WHO Expert Committee on Leprosy. Sixth report. Technical Report Series, No. 768. WHO: Geneva, 1988.

${ }^{4}$ Ponnighaus IM, Boerrigter G, Fine PEM, Ponnighaus JM, Russell J. Disabilities in leprosy patients ascertained in a total population survey in Karonga District, Northern Malawi. Le pr Rev, 1990; 61: 366-74. 
5 WHO collaborating centre for the epidemiology of leprosy. Global evaluation of the introduction of multidrug therapy. Leprosy Epidemiological Bulletin No. 6. Brussels: January 1991.

6 Mastro TD, Redd SC, Breiman RF. Imported leprosy in the United States, 1978 through 1988: an epidemic without secondary transmission. Am J Public Health, 1992; 82: 1127-30.

7 Paksoy N, Levi V. Preliminary assessment of multidrug therapy in leprosy patients in Western Samoa. $N Z$ Med J, 1989: 102: 589-91.

8 Montreewasuwat N, Peerapakorn S. Leprosy situation in Thailand. South-East Asian J. Trop. Med. Public Health, 1988; 19: 515-17.

9 Suite M, Edinborough NB. A second report on multidrug therapy for leprosy in Trinidad and Tobago. Lepr Rev. 1989; 60: 288-99.

10 Rangaraj M, Rangaraj J. Experience with multidrug therapy in Sierra Leone: clinical, operational and managerial analysis. Lepr Rev, 1986; 57 Suppl 3: 77-91.

11 Noordeen SK, Lopez Bravo L, Daumerie D. Global review of multidrug therapy (MDT) in leprosy. WHO Statistics Quarterly, 1991; 44: 2-15.

12 Byrd SR, Gelber RH. Effect of dapsone on haemoglobin concentration in patients with leprosy. Lepr Rev, 1991; 62: 171-8.

13 Powell RD, De Gowin RL, Bennett Eppes R, McNamara JV, Carson PE. The antimalarial and hemolytic properties of 4,4'-diaminodiphenyl sulf one (DDS). Int J Lep, 1967; 35: 590-667.

14 Jopling WH. Side effects of antileprosy drugs in common use (Editorial). Lepr Rev, 1983; 54: 261-70.

15 Mason GH, Ellis-Pegler RB, Arthur JF. Clof azamine and eosinophilic enteritis. Lepr Rev, 1977; 48: $175-80$.

16 Rose P. Reversal reactions in leprosy and their management (Editorial). Lepr Rev, 1991; 62: 113-21.

$17 \mathrm{Ji} \mathrm{B}$, Grosset JH. Recent advances in the chemotherapy of leprosy (Editorial). Lepr Rev, 1990; 61: 313-29. 


\title{
Les effets de la chimiothérapie de l'organisation mondiale pour la santé (oms) sur la lèpre importée à Auckland, Nouvelle Zélande, 1983-90
}

\author{
J. Cornwall, G. Cameron et R. B. Ellis-Pegler
}

Résumé De janvier 1983 à décembre 1990 à Auckland, Nouvelle Zélande, 87 malades-28 cas de maladie paucibacillaire (PBD) et 59 cas de maladie multibacillaire (MBD)—ont commencé la thérapeutique multidrogue (MDT) de l'OMS.

Tous étaient des immigrées venant des îles du Pacifique (65) ou d'Asie(22). Au total 57 malades avient déjà reçu des régimes non-OMS, quelques uns continuellement, mais souvent de façon intermittente, pendant de nombreuses années; 30 malades ont eu seulement MDT de l'OMS. En décembre 1990, 50 avaient terminé le traitement, avec 1 rechute et 1 réaction tardive, les deux chez des malades avec PBD traités seulement avec MDT de l'OMS. Il n'y a eu aucune rechute chez les malades traités par MDT de l'OMS après un traitement antérieur contre la lèpre.

Chez les multibacillaires, les réactions lépreuses de type II ont été moins nombreuses (16\%) chez ceux traités seulement par MDT de l'OMS que chez ceux traitées continuellement avant 1983 par d'autres régimes (64\%). Les réactions lépreuses de type I ont été observées chez $20 \%$ environ des deux groupes. L'index bactérien a baissé plus vite chez ceux qui avaient eu un traitement antérieur prolongé débutant avec MDT de l'OMS que chezceux dont le traitement MDT de l'OMS constituait la première chimiothérapie antilépreuse.

En général, nous avons constaté que MDT de l'OMS était bien supporté et le taux d'observance était bon, mais 13 malades (15\%) ont quitté Auckland avant la fin du traitement et $6(7 \%)$ pendant la période du suivi.

\section{Los efectos de la quimioterapie de la Organización Mundial de la Salud sobre la lepra importada, en Auckland, Nueva Zelandie, 1983-90}

\author{
J. Cornwall, G. Cameron y R. B. Ellis-Pegler
}

Resumen Se comenzo la quimioterapia de la Organización Mundial de la Salud (OMS) entre enero 1983 y diciembre 1990 en Auckland, Nueva Zelandia, sobre 87 pacientes (28 paucibacilares (PBD) y 59 multibacilares (MBD)).

Todos eran inmigrantes de las Islas del Pacífico (65) o de Asia (22). Un total de 57 pacientes ya habían realizado regímenes OMS por muchos años, algunos de forma continua, pero a menudo intermitente; 30 pacientes recibieron tratamiento multidroga OMS solamente. En diciembre 1990, 50 habián completado el tratamiento, con una recaída y una reacción retardada, ambos casos en pacientes con PCB tratados con MDT OMS solamente. No hubieron recaídas entre los tratados con MDT OMS después de un tratamiento posterior para la lepra.

En los casos con MBD, las reacciones leprosas de tipo II erán menos comunes (16\%) en los tratados solamente por MDT OMS que en los que habían sido tratados continuamente antes de 1983 con regímenes más antiguos (64\%). Se presentaron reacciones leprosas de tipo I en un $20 \%$ de ambos grupos. El índice bacteriano ba jó con más rapidez en los que habían tenido un tratamiento anterior prolongado que comenzaban MDT OMS que los que comenzaban MDT OMS como su tratamiento inicial contra la lepra.

En general, nuestra opinión es que MDT OMS ha sido bien aceptado y la conformidad ha sido buena, pero 13 pacientes (15\%) abandonaron Auckland antes de completar el tratamiento, y $6(7 \%)$ durante el estudio posterior. 